\title{
Plasma Amyloid- $\beta$ in Relation to Antibodies Against Herpes Simplex Virus, Cytomegalovirus, and Chlamydophila \\ pneumoniae
}

Karin Lopatko Lindman ${ }^{\mathrm{a}, *}$, Bodil Weidung ${ }^{\mathrm{a}, \mathrm{b}}$, Jan Olsson ${ }^{\mathrm{c}}$, Maria Josefsson ${ }^{\mathrm{d}}$, Anders Johansson ${ }^{\mathrm{e}, \mathrm{f}}$, Sture Eriksson ${ }^{\mathrm{a}, \mathrm{f}}$, Göran Hallmans ${ }^{\mathrm{f}}$, Fredrik Elgh ${ }^{\mathrm{c}}$ and Hugo Lövheim ${ }^{\mathrm{a}, \mathrm{g}}$

${ }^{\mathrm{a}}$ Department of Community Medicine and Rehabilitation, Geriatric Medicine, Umeå University, Umeå, Sweden

${ }^{\mathrm{b}}$ Department of Public Health and Caring Sciences, Geriatric Medicine, Uppsala University, Uppsala, Sweden

${ }^{\mathrm{c}}$ Department of Clinical Microbiology, Virology, Umeå University, Umeå, Sweden

${ }^{\mathrm{d}}$ Centre for Demographic and Ageing Research, Umeå University, Umeå, Sweden

${ }^{\mathrm{e}}$ Department of Odontology, Umeå University, Umeå, Sweden

${ }^{\mathrm{f}}$ Department of Public Health and Clinical Medicine, Umeå University, Umeå, Sweden

${ }^{\mathrm{g}}$ Wallenberg Centre for Molecular Medicine, Umeå University, Umeå, Sweden

Accepted 27 February 2021

Pre-press 11 March 2021

\section{Abstract.}

Background: Amyloid- $\beta$ (A $\beta$ ), the key constituent of Alzheimer's disease (AD) plaques, has antimicrobial properties. Objective: To investigate the association between plasma $A \beta$ and antibodies against the AD-related pathogens herpes simplex virus (HSV), cytomegalovirus (CMV), and C. pneumoniae.

Methods: Plasma from 339 AD cases, obtained on average 9.4 years $( \pm 4.00)$ before diagnosis, and their matched controls were analyzed for $A \beta_{40}$ and $A \beta_{42}$ concentrations with Luminex xMAP technology and INNOBIA plasma $A \beta$-form assays. Enzyme-linked immunosorbent assays were utilized for analyses of anti-HSV immunoglobulin (Ig) G, anti-HSV1 IgG, anti-HSV2 IgG, anti-CMV IgG, and anti-C. pneumoniae IgG. Follow-up samples were available for 150 of the cases.

Results: Presence and levels of anti-HSV1 IgG, anti-HSV2 IgG, anti-CMV IgG, and anti-C. pneumoniae IgG did not correlate with concentrations of $A \beta_{42}$ or $A \beta_{40}$ in cases or controls.

Conclusion: Levels of plasma $A \beta$ were not associated with antibodies against different AD-related pathogens.

Keywords: Alzheimer's disease, amyloid- $\beta$ peptides, Chlamydophila pneumoniae, cytomegalovirus, dementia, Herpes simplex, nested case-control study

\section{INTRODUCTION}

Alzheimer's disease (AD) is a terminal condition that affects millions of people worldwide. The

\footnotetext{
${ }^{*}$ Correspondence to: K. Lopatko Lindman, Department of Community Medicine and Rehabilitation, Geriatric Medicine, Umeå University, SE-901 85 Umeå, Sweden. Tel.: +46705877643; E-mail: karin.lopatko.lindman@umu.se.
}

etiology of sporadic AD is not completely understood, but a growing body of evidence points to an infectious component in AD development [1,2]. Herpes simplex virus type 1 (HSV1), cytomegalovirus (CMV), and Chlamydophila pneumoniae are all pathogens that have been associated with $\mathrm{AD}[3-10]$.

HSV1 is ubiquitous and found in approximately $80-90 \%$ of the adult population [11]. After primary infection, the virus persists latently in sensory 
neurons, most commonly in the trigeminal ganglion, and can subsequently reactivate. HSV1 has been detected in a high proportion of brains from $\mathrm{AD}$ patients and co-localizes with amyloid plaques in particular [12-16]. In epidemiological studies, carrying HSV1 has been associated with increased risk of AD, especially among genetically susceptible individuals [3-7, 17-21]. Similar to HSV1, the seroprevalance of CMV is high, reaching $80-90 \%$ in adults [11, 22]. Following primary infection, the virus remains latent in Tlymphocytes and can be reactivated repeatedly without causing symptoms [23]. Co-infection of CMV and HSV1 has been reported to increase the risk of developing $\mathrm{AD}[24,25]$. C. pneumoniae is a bacterium that can cause respiratory symptoms. Asymptomatic infection also occurs and approximately $60 \%$ of the adult population has serological evidence of C. pneumoniae infection [26].

The hypothesis of infectious involvement in $\mathrm{AD}$ corresponds well with the finding that amyloid- $\beta$ $(\mathrm{A} \beta)$ has potent antimicrobial activity [27-29]. Cultured cells accumulate $A \beta$ when infected with a broad spectrum of viruses (including HSV1 and CMV), bacteria, and fungi [9, 27, 29-33]. In addition, both HSV1 and C. pneumoniae infection lead to the formation of amyloid plaques in murine models [28, 29, 34-36]. Mice overexpressing $A \beta$ have greater survival rates compared to non-transgenic mice after brain infection [28, 29], suggesting a potential link between high levels of $A \beta$ and resistance to infection.

$\mathrm{A} \beta$ is primarily produced in the brain. However, there are potential extracerebral sources of $A \beta$, such as platelets [37, 38] and fibroblasts [9]. $A \beta$ containing 40 amino acids $\left(A \beta_{40}\right)$ is the most common variant of the $A \beta$ peptide in the central nervous system. The longer $A \beta_{42}$ fragment is the most amyloid-prone and is thus considered more neurotoxic than $A \beta_{40}$ [39]. Soluble plasma concentrations of both variants might vary as a consequence of pathogens infecting peripheral tissues. A previously published study showed that increased levels of anti-HSV IgM were associated with lower plasma levels of both $A \beta_{40}$ and $A \beta_{42}$ [40]. The correlation between plasma $A \beta$ levels and antibodies against CMV and C. pneumoniae has not been previously investigated.

Relationships between $A \beta_{40}$ and $A \beta_{42}$ in plasma and antibodies against different pathogens might indirectly support earlier findings that $A \beta$ has antimicrobial properties. Therefore, the aim of this study was to analyze the potential associations between plasma $A \beta$ levels and circulating antibodies against $\mathrm{HSV}, \mathrm{CMV}$, and C. pneumoniae.

\section{METHODS}

\section{Participants and procedures}

The nested case-control study used plasma samples previously donated and stored in the Medical Biobank in Umeå (Northern Sweden Health and Disease Study) [41]. A computerized procedure was employed to select AD cases with a suitable matched control. We identified 339 pairs of AD cases and matched controls who had been analyzed for $A \beta$. Controls were matched by sampling date, age, sex, and cohort from the Biobank material. In addition, follow-up samples were obtained for 150 of the 339 $\mathrm{AD}$ cases, collected between the time of the first sample and the date of diagnosis (ranging from 1 to 5 additional samples per subject, mean 1.59 samples \pm 0.84 , with a total of 251 follow-up samples). For this particular sample, analysis of $A \beta$ concentrations and the risk of AD development has previously been published [42]. The study was approved by the Regional Ethical Review Board in Umeå, Sweden (09-190M).

\section{AD diagnosis}

AD cases were diagnosed at the Memory Clinic of the University Hospital in Umeå according to the criteria of The Diagnostic and Statistical Manual of Mental Disorders, fourth edition [43], with a minimum of one brain-imaging technique. The clinical AD diagnoses were compatible with the National Institute of Neurological and Communicative Disorders and Stroke-Alzheimer's Disease and Related Disorders Association criteria [44]. Controls were confirmed free from major neurocognitive disorders and alive at the time of diagnosis for their corresponding $\mathrm{AD}$ patient using nation-wide registries. This procedure is described in detail in a previous publication [5].

\section{Plasma analysis}

$A \beta_{40}$ and $A \beta_{42}$ concentrations were determined with Luminex xMAP technology and the INNOBIA plasma $A \beta$-form assays (Innogenetics, Ghent, Belgium) [45]. In-house enzyme-linked immunosorbent assays (ELISA) were used for the analysis of antiHSV IgG and anti-CMV IgG antibodies, as described in a previous publication [46]. Commercial ELISA kits were utilized for the analysis of anti-HSV1 IgG, anti-HSV2 IgG (HerpeSelect 1, HerpeSelect 2, 
FOCUS Diagnostics), and anti-C. pneumoniae (SeropCp ${ }^{\mathrm{TM}}$ Quant $\left.\mathrm{IgG}\right)$.

To establish carriage of HSV1, HSV2, or both, each anti-HSV IgG-positive sample was further analyzed for anti-HSV2 IgG. If positive, an additional analysis was conducted for anti-HSV1 IgG to differentiate between HSV1 positive, HSV2 positive, and HSV1 + HSV2-positive individuals.

\section{Statistical analysis}

Linear regression analyses of $\mathrm{A} \beta$ and antibodies against HSV, HSV1, HSV2, CMV, and C. pneumoniae were performed separately in groups of cases and controls. Age and sex were included in the linear regression models as potential confounders, if they were significantly associated with both the dependent and the independent variables in that particular regression. Pearson's correlation, Student's $t$-test, the chi-squared test, and Fischer's exact test were used for these analyses as appropriate.

The paired-sample $t$-test and McNemar's test were used to compare differences between the matched groups concerning the presence of anti-HSV, antiHSV1 IgG, anti-HSV2 IgG, anti-CMV, and anti- $C$. pneumoniae $\mathrm{IgG}$ antibodies.

Linear mixed models were fitted to analyze $A \beta$ plasma concentrations over time and seropositivity for different antibodies among AD patients with repeated samples. In this model, time was defined as the number of years between the sampling and diagnosis date. The interactions between sex and age with time were considered potential confounders if significantly associated with antibody seropositivity. The models were performed in $\mathrm{R}$ version 3.4.3 using the "Ime4 package" and included a subject-specific random intercept to account for within-subject correlations between repeated measurements.

The assumptions of the linear mixed and regression models were tested before carrying out the analyses. $\mathrm{A} \beta$ was plotted against follow-up time and IgG levels to visualize their relationship. Normality was evaluated with Q-Q plots and simple histograms of the distribution of $A \beta$ in different groups. Levene's test were used to assess the homogeneity of variance.

SPSS Statistics version 24 (IBM Corporation, Armonk, NY) was used for statistical analyses, with a $p$-value of $<0.05$ being interpreted as statistically significant. $p$ values were adjusted for multiple comparisons by the Bonferroni correction method $(n=18$ analyses for $A \beta_{40}$ and $A \beta_{42}$ respectively).

\section{RESULTS}

The study enrolled 339 cases with AD and 339 matched controls ( $76.4 \%$ females). The mean age at plasma sampling was 61.3 years in both groups and the mean age at diagnosis was 70.8 years (Table 1). AD cases had significantly higher seroprevalence of anti-HSV IgG compared to their controls $(94.4 \%$ versus $89.7 \%$, respectively, $p=0.030$; Table 1$)$. Otherwise, no differences between the groups were observed in terms of A $\beta$ plasma concentrations and the presence of anti-HSV1 IgG, anti-HSV2 IgG, antiCMV IgG, or anti-C. pneumoniae IgG antibodies (Table 1).

Table 1

Basic characteristics of the sample

\begin{tabular}{|c|c|c|c|c|}
\hline & $\begin{array}{c}\text { AD cases } \\
n=339\end{array}$ & $\begin{array}{c}\text { Controls } \\
n=339\end{array}$ & $\begin{array}{l}\text { AD cases with } \\
\text { repeated samples } \\
\quad n=150^{1}\end{array}$ & $\begin{array}{c}p \text { for differences } \\
\text { between cases } \\
\text { and controls }{ }^{2}\end{array}$ \\
\hline Age at sampling $(y)$, mean \pm SD & $61.3 \pm 5.6$ & $61.3 \pm 5.6$ & $59.8 \pm 5.5$ & \\
\hline Age at diagnosis $(y)$, mean $\pm S D$ & $70.8 \pm 6.4$ & & $70.3 \pm 6.3$ & \\
\hline $\mathrm{A} \beta_{42}(\mathrm{ng} / \mathrm{L})$, mean $\pm \mathrm{SD}$ & $43.6 \pm 13.1$ & $44.6 \pm 12.5$ & $43.5 \pm 12.5$ & 0.316 \\
\hline $\mathrm{A} \beta_{40}(\mathrm{ng} / \mathrm{L})$, mean $\pm \mathrm{SD}$ & $142.3 \pm 36.3$ & $143.9 \pm 41.0$ & $140.9 \pm 37.9$ & 0.525 \\
\hline Sex (female), n (\%) & $259(76.4)$ & $259(76.4)$ & $141(94.0)$ & \\
\hline anti-HSV IgG+, n $(\%)^{3}$ & $320(94.4)$ & $304(89.7)$ & $143(95.3)$ & 0.030 \\
\hline anti-HSV1 IgG+, $\mathrm{n}(\%)^{3}$ & $311(91.7)$ & $297(87.6)$ & $142(94.7)$ & 0.075 \\
\hline anti-HSV2 IgG+, $\mathrm{n}(\%)^{3}$ & $49(14.5)$ & $43(12.7)$ & $14(9.3)$ & 0.450 \\
\hline anti-CMV IgG+, n (\%) & $293(86.4)$ & $299(88.2)$ & $135(90.0)$ & 0.485 \\
\hline anti-C. pneumoniae $\operatorname{IgG}+, \mathrm{n}(\%)$ & $209(61.7)$ & $205(60.5)$ & $88(58.7)$ & 0.737 \\
\hline anti-HSV IgM+, n (\%) & $24(7.1)$ & $18(11.8)$ & $14(9.3)$ & 0.411 \\
\hline anti-CMV IgM+, n (\%) & $10(2.9)$ & $12(3.5)$ & $4(2.7)$ & 0.491 \\
\hline
\end{tabular}

$\mathrm{AD}$, Alzheimer's disease; y, years; SD, standard deviation; $\mathrm{A} \beta$, amyloid- $\beta$; HSV, herpes simplex virus; Ig, immunoglobulin; CMV, cytomegalovirus; ${ }^{1}$ At baseline. ${ }^{2}$ Comparison between "AD cases, $n=339$ " and "Controls, $n=339$ ". ${ }^{3} 40$ subjects $(11.8 \%)$ were positive for both anti-HSV1 and anti-HSV2 IgG among the cases, and 18 (5.3\%) subjects were positive for both anti-HSV1 and anti-HSV2 IgG among the controls, and $13(8.7 \%)$ subjects were positive for anti-HSV1 and anti-HSV2 IgG among the cases with repeated samples. 
Table 2

Simple linear regression with plasma concentrations of free $A \beta$ in relation to seropositivity for antibodies (indicating carriage of a pathogen)

\begin{tabular}{|c|c|c|c|c|c|c|c|c|}
\hline & \multicolumn{4}{|c|}{$\mathrm{A} \beta_{42}$} & \multicolumn{4}{|c|}{$\mathrm{A} \beta_{40}$} \\
\hline & \multicolumn{2}{|c|}{ AD cases } & \multicolumn{2}{|c|}{ Controls } & \multicolumn{2}{|c|}{ AD cases } & \multicolumn{2}{|c|}{ Controls } \\
\hline & $\beta$ & $p, p_{\text {adj. }}{ }^{1}$ & $\beta$ & $p, p_{\text {adj. }}{ }^{1}$ & $\beta$ & $p, p_{\text {adj. }}{ }^{1}$ & $\beta$ & $p, p_{\text {adj }} .{ }^{1}$ \\
\hline anti-HSV1 IgG+ & -0.018 & $0.735,1.000$ & 0.085 & $0.117,1.000$ & -0.039 & $0.479,1.000$ & -0.029 & $0.599,1.000$ \\
\hline anti-HSV2 IgG+ & 0.079 & $0.145,1.000$ & -0.039 & $0.476,1.000$ & 0.132 & $0.015,0.270$ & -0.013 & $0.805,1.000$ \\
\hline anti-CMV IgG+ & 0.018 & $0.743,1.000$ & -0.013 & $0.806,1.000$ & $-0.068^{2}$ & $0.210,1.000$ & -0.001 & $0.980,1.000$ \\
\hline $\begin{array}{l}\text { anti-C. pneumoniae } \\
\operatorname{IgG}+\end{array}$ & -0.042 & $0.438,1.000$ & 0.060 & $0.271,1.000$ & 0.014 & $0.791,1.000$ & -0.113 & $0.038,0.684$ \\
\hline
\end{tabular}

$\mathrm{A} \beta$, amyloid- $\beta$; $\mathrm{AD}$, Alzheimer's disease; HSV, herpes simplex virus; Ig, immunoglobulin; CMV, cytomegalovirus; $C$. pneumoniae, Chlamydophila pneumonia; ${ }^{1}$ Adjusted for multiple comparisons by Bonferroni correction, $n=18$ analyses for $\mathrm{A} \beta_{40}$ and $\mathrm{A} \beta_{42}$ respectively. ${ }^{2}$ Adjusted for sex.

Table 3

Simple linear regression with plasma concentrations of free $A \beta$ in relation to levels of antibodies

\begin{tabular}{|c|c|c|c|c|c|c|c|c|}
\hline & \multicolumn{4}{|c|}{$\mathrm{A} \beta_{42}$} & \multicolumn{4}{|c|}{$\mathrm{A} \beta_{40}$} \\
\hline & \multicolumn{2}{|c|}{ AD cases } & \multicolumn{2}{|c|}{ Controls } & \multicolumn{2}{|c|}{ AD cases } & \multicolumn{2}{|c|}{ Controls } \\
\hline & $\beta$ & $p, p_{\text {adj. }}{ }^{1}$ & $\beta$ & $p, p_{\text {adj }} .1$ & $\beta$ & $p, p_{\text {adj. }}{ }^{1}$ & $\beta$ & $p, p_{\text {adj }}{ }^{1}$ \\
\hline anti-HSV IgG levels ${ }^{1}$ & 0.016 & $0.769,1.000$ & -0.087 & $0.130,1.000$ & 0.090 & $0.736,1.000$ & 0.081 & $0.157,1.000$ \\
\hline anti-CMV IgG levels ${ }^{1}$ & -0.034 & $0.567,1.000$ & -0.127 & $0.028,0.504$ & $-0.019^{2}$ & $0.751,1.000$ & -0.088 & $0.127,1.000$ \\
\hline $\begin{array}{l}\text { anti-C. pneumoniae } \\
\text { IgG levels }^{1}\end{array}$ & -0.063 & $0.363,1.000$ & 0.004 & $0.951,1.000$ & 0.053 & $0.449,1.000$ & 0.097 & $0.168,1.000$ \\
\hline
\end{tabular}

$\mathrm{A} \beta$, amyloid- $\beta$; AD; Alzheimer's disease; HSV, herpes simplex virus; Ig, immunoglobulin; CMV, cytomegalovirus; C. pneumoniae,

${ }^{1}$ Adjusted for multiple comparisons by Bonferroni correction, $n=18$ analyses for $\mathrm{A} \beta_{40}$ and $\mathrm{A} \beta_{42}$ respectively. ${ }^{2}$ Adjusted for sex.

Table 4

Mixed linear model with the interaction between follow-up time and seropositivity on $\mathrm{A} \beta$ plasma concentrations among individuals with Alzheimer's disease

\begin{tabular}{|c|c|c|c|c|}
\hline \multirow[b]{2}{*}{$\begin{array}{l}\text { Interaction with } \\
\text { follow-up time }\end{array}$} & \multicolumn{2}{|c|}{$\mathrm{A} \beta_{42}$} & \multicolumn{2}{|c|}{$\mathrm{A} \beta_{40}$} \\
\hline & Estimate $^{1} \pm \mathrm{SE}$ & $p, p_{\text {adj }}{ }^{2}$ & Estimate $\pm \mathrm{SE}$ & $p, p_{\mathrm{adj}} .^{2}$ \\
\hline anti-HSV1 IgG+ $\times$ time $^{3}$ & $-0.582 \pm 0.507$ & $0.251,1.000$ & $0.426 \pm 1.717$ & $0.804,1.000$ \\
\hline anti-HSV2 IgG $+\times$ time $^{3}$ & $0.150 \pm 0.415$ & $0.718,1.000$ & $-0.517 \pm 1.327$ & $0.697,1.000$ \\
\hline anti-CMV IgG $+\times$ time $^{3}$ & $-0.241 \pm 0.4107$ & $0.558,1.000$ & $-1.424 \pm 1.384$ & $0.304,1.000$ \\
\hline $\begin{array}{l}\text { anti-C. pneumoniae } \\
\qquad \mathrm{IgG}+\times \text { time }^{3}\end{array}$ & $0.398 \pm 0.254$ & $0.119,1.000$ & $-1.997 \pm 0.844$ & $0.018,0.324$ \\
\hline
\end{tabular}

$\mathrm{A} \beta$, amyloid- $\beta$; HSV, herpes simplex virus; Ig, immunoglobulin; CMV, cytomegalovirus; ${ }^{1}$ Estimated yearly change in nanograms/liter. ${ }^{2}$ Adjusted for multiple comparisons by Bonferroni correction, $n=18$ analyses for $\mathrm{A} \beta_{40}$ and $\mathrm{A} \beta_{42}$ respectively. ${ }^{3}$ The analysis included subjects with $\mathrm{AD}$ and repeated measurements (i.e., follow-up samples), number $=163$.

Neither $A \beta_{42}$ nor $A \beta_{40}$ levels were, after adjustment for multiple comparisons, associated with presence or levels of anti-HSV1 IgG, anti-HSV2 IgG, anti-CMV IgG and anti-C. pneumoniae IgG (Tables 2 and 3).

Plasma concentrations of $A \beta_{42}$ and $A \beta_{40}$ in relation to follow-up time among $\mathrm{AD}$ patients were not affected by age ( $p=0.367$ and $p=0.911$, respectively) or sex ( $p=0.618$ and $p=0.997$, respectively). There were no significant interactions between follow-up time and the presence of anti-HSV1 IgG, anti-HSV2 $\mathrm{IgG}$, anti-CMV IgG, and anti-C. pneumoniae IgG in association with $A \beta_{42}$ and $A \beta_{40}$ after adjustment for multiple comparisons (Table 4).

\section{DISCUSSION}

This nested case-control study included a large number of thoroughly diagnosed $\mathrm{AD}$ cases and closely matched controls, with plasma samples taken on average almost 10 years prior to diagnosis. The study material was therefore well suited to investigate whether biochemical markers for AD correlate with 
infectious agents. Here, we specifically investigated the prevalence and titers of $\operatorname{IgG}$ towards possible AD-related pathogens and the concentrations of free, soluble $A \beta_{42}$ and $A \beta_{40}$.

We found that $A \beta$ concentrations did not correlate with antibodies against the different pathogens investigated. While the unadjusted analyses indicated a few associations, no clear patter emerged. None of these associations were significant after adjustment for multiple comparisons. Our negative results, therefore, do not indicate that $A \beta$ is directly involved in managing $\mathrm{AD}$-associated infections in the periphery. An early hypothesis was that the preclinical $\mathrm{AD}$ patients would react differently concerning $\mathrm{A} \beta$ concentrations in response to infection, possibly revealing altered ability to control peripheral infections, but no clear pattern was observed as to differences in the associations between $\mathrm{AD}$ cases and their controls. Importantly, we measured IgG antibodies, which can be considered markers of latent or chronic infection. Presence of IgG directed towards a specific pathogen could indicate carriage, while higher IgG levels could possibly reflect a more active or recently triggered immune response. Latent HSV1 is mainly localized to the trigeminal ganglia. At this locale, non-reactivating virus may not be exposed to the peripheral immune system, which could explain the lack of an association between anti-HSV1 IgG and plasma $A \beta$. It should also be noted that concentrations of free plasma $A \beta$ do not necessarily correlate with concentrations of $A \beta$ in the central nervous system and our results are not representative of intracerebral processes [42].

In the present study, AD cases had a significantly higher proportion of HSV seropositives compared to controls. This corresponds well with the growing evidence for an association between HSV1 and AD development $[1,3]$.

A limitation of the study is the small number of anti-HSV IgM seropositive individuals, making it difficult to investigate whether IgM antibodies might correlate with $A \beta$ concentrations, an association which has been detected in a previous study [40]. Another limitation was that follow-up samples were available only for a subset of the AD cases, making it impossible to compare the groups of cases and controls with respect to the presence of antibodies and $\mathrm{A} \beta$ concentrations over time.

In conclusion, this large nested case-control study indicates that plasma $A \beta$ concentrations are not associated with antibodies against AD-related pathogens (viruses and bacteria). Investigations of other cohorts will be needed to confirm the findings of this study as well as to determine the predictive value of serum biomarkers for later $\mathrm{AD}$ development.

\section{ACKNOWLEDGMENTS}

This study was conducted in the context of the CHANCES project, which was funded in the FP7 framework program of DG-RESEARCH in the European Commission. The study was further supported financially by grants from the Västerbotten County Council, the Kempe Foundations, Wallenberg Centre for Molecular Medicine in Umeå, the Swedish Medical Association, the Swedish Dementia Association, the Trolle-Wachtmeister Foundation, the Dementia Fund in Västerbotten, the Swedish Alzheimer Fund, the Stohne Foundation, the Bergvall Foundation, and the Umeå University Foundation for Medical Research.

\section{CONFLICT OF INTEREST}

The authors have no conflict of interest to report.

\section{REFERENCES}

[1] Itzhaki RF, Lathe R, Balin BJ, Ball MJ, Bearer EL, Braak H, Bullido MJ, Carter C, Clerici M, Cosby SL, Del Tredici K, Field H, Fulop T, Grassi C, Griffin WS, Haas J, Hudson AP, Kamer AR, Kell DB, Licastro F, Letenneur L, Lovheim H, Mancuso R, Miklossy J, Otth C, Palamara AT, Perry G, Preston C, Pretorius E, Strandberg T, Tabet N, TaylorRobinson SD, Whittum-Hudson JA (2016) Microbes and Alzheimer's disease. J Alzheimers Dis 51, 979-984.

[2] Haas JG, Lathe R (2018) Microbes and Alzheimer's disease: New findings call for a paradigm change. Trends Neurosci 41, 570-573.

[3] Steel AJ, Eslick GD (2015) Herpes viruses increase the risk of Alzheimer's disease: A meta-analysis. J Alzheimers Dis 47, 351-364.

[4] Lovheim H, Gilthorpe J, Adolfsson R, Nilsson LG, Elgh F (2015) Reactivated herpes simplex infection increases the risk of Alzheimer's disease. Alzheimers Dement 11, 593599.

[5] Lovheim H, Gilthorpe J, Johansson A, Eriksson S, Hallmans G, Elgh F (2015) Herpes simplex infection and the risk of Alzheimer's disease: A nested case-control study. Alzheimers Dement 11, 587-592.

[6] Tzeng NS, Chung CH, Lin FH, Chiang CP, Yeh CB, Huang SY, Lu RB, Chang HA, Kao YC, Yeh HW, Chiang WS, Chou YC, Tsao CH, Wu YF, Chien WC (2018) Anti-herpetic medications and reduced risk of dementia in patients with herpes simplex virus infections-a nationwide, populationbased cohort study in Taiwan. Neurotherapeutics 15, 417429.

[7] Lopatko Lindman K, Hemmingsson E-S, Weidung B, Brannstrom J, Josefsson M, Olsson J, Elgh F, Nordstrom 
P, Lovheim H (2021) Herpes virus infections, antiviral treatment and the risk of dementia - a registry-based cohort study in Sweden. Alzheimers Dement (N Y) 7, e12119.

[8] Barnes LL, Capuano AW, Aiello AE, Turner AD, Yolken RH, Torrey EF, Bennett DA (2015) Cytomegalovirus infection and risk of Alzheimer disease in older black and white individuals. J Infect Dis 211, 230-237.

[9] Lurain NS, Hanson BA, Martinson J, Leurgans SE, Landay AL, Bennett DA, Schneider JA (2013) Virological and immunological characteristics of human cytomegalovirus infection associated with Alzheimer disease. J Infect Dis 208, 564-572.

[10] Balin BJ, Gerard HC, Arking EJ, Appelt DM, Branigan PJ, Abrams JT, Whittum-Hudson JA, Hudson AP (1998) Identification and localization of Chlamydia pneumoniae in the Alzheimer's brain. Med Microbiol Immunol 187, 23-42.

[11] Olsson J, Kok E, Adolfsson R, Lovheim H, Elgh F (2017) Herpes virus seroepidemiology in the adult Swedish population. Immun Ageing 14, 10.

[12] Wozniak MA, Mee AP, Itzhaki RF (2009) Herpes simplex virus type 1 DNA is located within Alzheimer's disease amyloid plaques. J Pathol 217, 131-138.

[13] Wozniak MA, Shipley SJ, Combrinck M, Wilcock GK, Itzhaki RF (2005) Productive herpes simplex virus in brain of elderly normal subjects and Alzheimer's disease patients. J Med Virol 75, 300-306.

[14] Olsson J, Lovheim H, Honkala E, Karhunen PJ, Elgh F, Kok EH (2016) HSV presence in brains of individuals without dementia: The TASTY brain series. Dis Model Mech $\mathbf{9}$, 1349-1355.

[15] Readhead B, Haure-Mirande JV, Funk CC, Richards MA, Shannon P, Haroutunian V, Sano M, Liang WS, Beckmann ND, Price ND, Reiman EM, Schadt EE, Ehrlich ME, Gandy S, Dudley JT (2018) Multiscale analysis of independent alzheimer's cohorts finds disruption of molecular, genetic, and clinical networks by human Herpesvirus. Neuron 99, 64-82.e67.

[16] Jamieson GA, Maitland NJ, Wilcock GK, Craske J, Itzhaki RF (1991) Latent herpes simplex virus type 1 in normal and Alzheimer's disease brains. J Med Virol 33, 224-227.

[17] Letenneur L, Peres K, Fleury H, Garrigue I, BarbergerGateau P, Helmer C, Orgogozo JM, Gauthier S, Dartigues JF (2008) Seropositivity to herpes simplex virus antibodies and risk of Alzheimer's disease: A population-based cohort study. PLoS One 3, e3637.

[18] Lovheim H, Norman T, Weidung B, Olsson J, Josefsson M, Adolfsson R, Nyberg L, Elgh F (2019) Herpes simplex virus, APOEvarepsilon4, and cognitive decline in old age: Results from the Betula Cohort Study. J Alzheimers Dis 67, 211-220.

[19] Lopatko Lindman K, Weidung B, Olsson J, Josefsson M, Kok E, Johansson A, Eriksson S, Hallmans G, Elgh F, Lövheim H (2019) A genetic signature including apolipoprotein $\mathrm{E} \varepsilon 4$ potentiates the risk of herpes simplex-associated Alzheimer's disease. Alzheimers Dement (N Y) 5, 697-704.

[20] Pandey JP, Olsson J, Weidung B, Kothera RT, Johansson A, Eriksson S, Hallmans G, Elgh F, Lövheim H (2020) An Ig $\gamma$ marker genotype is a strong risk factor for Alzheimer disease, independent of apolipoprotein E $\varepsilon 4$ genotype. $J$ Immunol 205, 1318-1322.

[21] Linard M, Letenneur L, Garrigue I, Doize A, Dartigues JF, Helmer C (2020) Interaction between APOE4 and herpes simplex virus type 1 in Alzheimer's disease. Alzheimers Dement 16, 200-208.
[22] Staras SA, Dollard SC, Radford KW, Flanders WD, Pass RF, Cannon MJ (2006) Seroprevalence of cytomegalovirus infection in the United States, 1988-1994. Clin Infect Dis 43, 1143-1151.

[23] Soderberg-Naucler C, Fornara O, Rahbar A (2016) Cytomegalovirus driven immunosenescence-An immune phenotype with or without clinical impact? Mech Ageing Dev 158, 3-13.

[24] Lovheim H, Olsson J, Weidung B, Johansson A, Eriksson S, Hallmans G, Elgh F (2018) Interaction between cytomegalovirus and herpes simplex virus type 1 associated with the risk of Alzheimer's disease development. $J$ Alzheimers Dis 61, 939-945.

[25] Strandberg TE, Pitkala KH, Linnavuori KH, Tilvis RS (2003) Impact of viral and bacterial burden on cognitive impairment in elderly persons with cardiovascular diseases. Stroke 34, 2126-2131.

[26] Miyashita N, Niki Y, Nakajima M, Fukano H, Matsushima T (2001) Prevalence of asymptomatic infection with Chlamydia pneumoniae in subjectively healthy adults. Chest 119, 1416-1419.

[27] Soscia SJ, Kirby JE, Washicosky KJ, Tucker SM, Ingelsson M, Hyman B, Burton MA, Goldstein LE, Duong S, Tanzi RE, Moir RD (2010) The Alzheimer's disease-associated amyloid beta-protein is an antimicrobial peptide. PLoS One 5, e9505.

[28] Kumar DK, Choi SH, Washicosky KJ, Eimer WA, Tucker S, Ghofrani J, Lefkowitz A, McColl G, Goldstein LE, Tanzi RE, Moir RD (2016) Amyloid-beta peptide protects against microbial infection in mouse and worm models of Alzheimer's disease. Sci Transl Med 8, 340ra372.

[29] Eimer WA, Vijaya Kumar DK, Navalpur Shanmugam NK, Rodriguez AS, Mitchell T, Washicosky KJ, Gyorgy B, Breakefield XO, Tanzi RE, Moir RD (2018) Alzheimer's disease-associated beta-amyloid is rapidly seeded by herpesviridae to protect against brain infection. Neuron 99, 56-63.e53.

[30] Wozniak MA, Itzhaki RF, Shipley SJ, Dobson CB (2007) Herpes simplex virus infection causes cellular beta-amyloid accumulation and secretase upregulation. Neurosci Lett $\mathbf{4 2 9}$, 95-100.

[31] Santana S, Recuero M, Bullido MJ, Valdivieso F, Aldudo J (2012) Herpes simplex virus type I induces the accumulation of intracellular beta-amyloid in autophagic compartments and the inhibition of the non-amyloidogenic pathway in human neuroblastoma cells. Neurobiol Aging 33, 430.e419433.

[32] Piacentini R, Civitelli L, Ripoli C, Marcocci ME, De Chiara G, Garaci E, Azzena GB, Palamara AT, Grassi C (2011) HSV-1 promotes Ca2+-mediated APP phosphorylation and Abeta accumulation in rat cortical neurons. Neurobiol Aging 32, 2323.e2313-2326.

[33] Cairns DM, Rouleau N, Parker RN, Walsh KG, Gehrke L, Kaplan DL (2020) A 3D human brain-like tissue model of herpes-induced Alzheimer's disease. Sci Adv 6, eaay8828.

[34] Little CS, Joyce TA, Hammond CJ, Matta H, Cahn D, Appelt DM, Balin BJ (2014) Detection of bacterial antigens and Alzheimer's disease-like pathology in the central nervous system of BALB/c mice following intranasal infection with a laboratory isolate of Chlamydia pneumoniae. Front Aging Neurosci 6, 304.

[35] De Chiara G, Piacentini R, Fabiani M, Mastrodonato A, Marcocci ME, Limongi D, Napoletani G, Protto V, Coluccio P, Celestino I, Li Puma DD, Grassi C, Palamara AT (2019) Recurrent herpes simplex virus-1 infection induces 
hallmarks of neurodegeneration and cognitive deficits in mice. PLoS Pathog 15, e1007617.

[36] Tanaka S, Nagashima H (2018) Establishment of an Alzheimer's disease model with latent herpesvirus infection using PS2 and Tg2576 double transgenic mice. Exp Anim 67, 185-192.

[37] Chen M, Inestrosa NC, Ross GS, Fernandez HL (1995) Platelets are the primary source of amyloid beta-peptide in human blood. Biochem Biophys Res Commun 213, 96-103.

[38] Inyushin M, Zayas-Santiago A, Rojas L, Kucheryavykh L (2020) On the role of platelet-generated amyloid beta peptides in certain amyloidosis health complications. Front Immunol 11, 571083.

[39] Kopan R, Goate A (2000) A common enzyme connects notch signaling and Alzheimer's disease. Genes Dev 14, 2799-2806.

[40] Feart C, Helmer C, Fleury H, Bejot Y, Ritchie K, Amouyel P, Schraen-Maschke S, Buee L, Lambert JC, Letenneur L, Dartigues JF (2011) Association between IgM anti-herpes simplex virus and plasma amyloid-beta levels. PLoS One 6, e29480.

[41] Hallmans G, Agren A, Johansson G, Johansson A, Stegmayr B, Jansson JH, Lindahl B, Rolandsson O, Soderberg S, Nilsson M, Johansson I, Weinehall L (2003) Cardiovascular disease and diabetes in the Northern Sweden Health and Disease Study Cohort - evaluation of risk factors and their interactions. Scand J Public Health Suppl 61, 18-24.
[42] Lövheim H, Elgh F, Johansson A, Zetterberg H, Blennow K, Hallmans G, Eriksson S (2016) Plasma concentrations of free amyloid-beta cannot predict the development of Alzheimer's disease. Alzheimers Dement 13, 778-782.

[43] American Psychiatric Association (2000) Diagnostic and Statistical Manual of Mental Disorders. 4th ed. Text Revision. American Psychiatric Association, Washington, DC.

[44] McKhann G, Drachman D, Folstein M, Katzman R, Price D, Stadlan EM (1984) Clinical diagnosis of Alzheimer's disease: Report of the NINCDS-ADRDA Work Group under the auspices of Department of Health and Human Services Task Force on Alzheimer's Disease. Neurology 34, 939-944.

[45] Hansson O, Zetterberg H, Vanmechelen E, Vanderstichele $\mathrm{H}$, Andreasson U, Londos E, Wallin A, Minthon L, Blennow K (2010) Evaluation of plasma Abeta(40) and Abeta(42) as predictors of conversion to Alzheimer's disease in patients with mild cognitive impairment. Neurobiol Aging 31, 357367.

[46] Sjostrom S, Hjalmars U, Juto P, Wadell G, Hallmans G, Tjonneland A, Halkjaer J, Manjer J, Almquist M, Melin BS (2011) Human immunoglobulin G levels of viruses and associated glioma risk. Cancer Causes Control 22, 12591266. 